\title{
(2) OPEN ACCESS \\ Weeping wounds and sepsis: a complication of elephantiasis nostras verrucosa
}

\author{
Kenny Vongbunyong 주, Chayan Chakraborti
}

Department of Medicine, Tulane University School of Medicine, New Orleans, Louisiana, USA

\section{Correspondence to} Kenny Vongbunyong; kennyvongbunyong@gmail.com

Accepted 13 January 2021

\section{DESCRIPTION}

A 68-year-old man with atrial fibrillation, morbid obesity, heart failure and venous stasis dermatitis presented to the emergency department after a presyncopal episode. On arrival he was febrile, hypotensive, tachycardic and found to have leucocytosis, which led to concerns for septic shock. Blood cultures grew group C Streptococcus, prompting treatment with intravenous ceftriaxone. Physical examnation showed extensive bilateral leg swelling with extreme hyperpigmented skin accompanied by multiple keratotic papules and plaques draining white malodorous discharge (figure 1). The patient reported the discharge started 6 months prior, while the nodules developed over the course of 2 years and extended from the malleolus to a few centimetres below the knee. These findings were suggestive of the diagnosis of elephantiasis nostras verrucosa (ENV) superimposed on chronic venous stasis dermatitis. The patient received aggressive diuresis to address the heart failure exacerbation, which led to reduced swelling of his bilateral lower extremities and flattening of the papules and plaques (figure 2).

ENV is a rare complication of non-filarial chronic secondary lymphoedema that can be caused by conditions impairing lymphatic drainage including recurring erysipelas and cellulitis, congestive heart failure, obesity and chronic venous stasis. Additionally, ENV can be caused by malignancies such as lymphoma, which can impede lymphatic drainage, and soft-tissue trauma which can introduce bacteria to cause infections. ${ }^{1}$ In particular, obesity and congestive heart failure are two causes of secondary

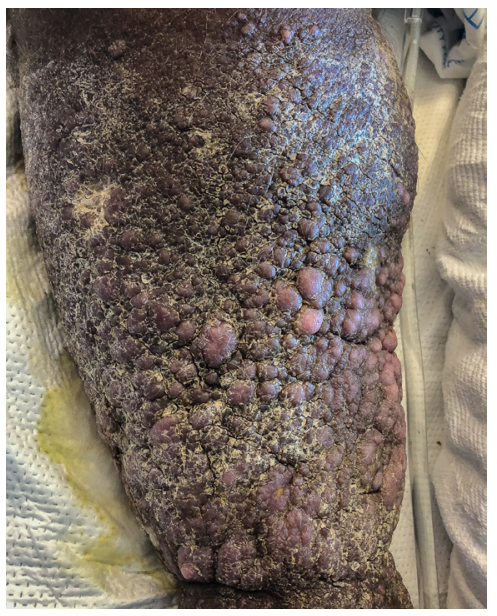

Figure 1 Characteristic 'tree-bark' appearance of ENV showing multiple keratotic papules and plaques. ENV, elephantiasis nostras verrucosa.

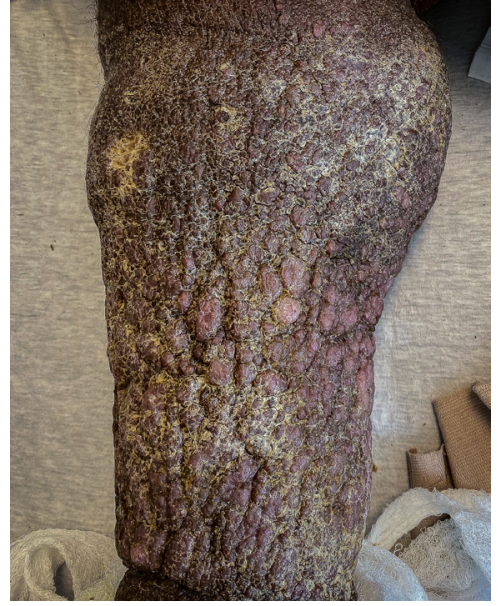

Figure 2 Lower right extremity after diuresis.

lymphoedema which have increasing prevalence in the USA and can be expected to accompany ENV more frequently in the future. ${ }^{2} \mathrm{ENV}$ is a progressive condition that can lead to irreversible disfiguring skin changes and interfere with ambulation. This case reports sepsis as a consequence of streptococcus skin infection in a patient with ENV, further highlighting the importance of early identification and intervention.

\section{Patient's perspective}

'I was not bothered by my legs since I was worried about the bigger things like my heart hurting and the A. fib which was occurring all the time. My legs were painless but it started getting worse and worse as the year went on. Then fluid started leaking out like a faucet and whenever I would sit, there would be a puddle. It must have been the infection trying to get out. I am glad that everything is getting taken care of. My legs today are so much better you would think they were a new set of legs.'

\section{Learning points}

Elephantiasis nostras verrucosa (ENV) is a rare non-filarial form of lymphoedema seen in patients with chronic secondary lymphoedema.

- It is important to recognise and treat ENV early, as the condition can cause irreversible skin changes, interfere with ambulation and increase a patient's risk for infections. 
Contributors KV examined and interviewed the patient and $\mathrm{CC}$ treated the patient. KV drafted the manuscript and CC reviewed it. Both authors approved the manuscript for submission.

Funding The authors have not declared a specific grant for this research from any funding agency in the public, commercial or not-for-profit sectors.

Competing interests None declared.

Patient consent for publication Obtained.

Provenance and peer review Not commissioned; externally peer reviewed.

Open access This is an open access article distributed in accordance with the Creative Commons Attribution Non Commercial (CC BY-NC 4.0) license, which permits others to distribute, remix, adapt, build upon this work non-commercially, and license their derivative works on different terms, provided the original work is properly cited and the use is non-commercial. See: http://creativecommons.org/ licenses/by-nc/4.0/.

\section{ORCID iD}

Kenny Vongbunyong http://orcid.org/0000-0002-2852-4127

\section{REFERENCES}

1 Sisto K, Khachemoune A. Elephantiasis nostras verrucosa: a review. Am J Clin Dermatol 2008;9:141-6.

2 Baird D, Bode D, Akers T. Env): a complication of congestive heart failure and obesity. J Am Board Fam Med 2010;23:413-7.

Copyright 2021 BMJ Publishing Group. All rights reserved. For permission to reuse any of this content visit

https://www.bmi.com/company/products-services/rights-and-licensing/permissions/

BMJ Case Report Fellows may re-use this article for personal use and teaching without any further permission.

Become a Fellow of BMJ Case Reports today and you can:

- Submit as many cases as you like

Enjoy fast sympathetic peer review and rapid publication of accepted articles

Access all the published articles

Re-use any of the published material for personal use and teaching without further permission

Customer Service

If you have any further queries about your subscription, please contact our customer services team on +44 (0) 2071111105 or via email at support@bmj.com.

Visit casereports.bmj.com for more articles like this and to become a Fellow 